\section{Secret treasure-troves restored}

\section{Reflecting on the endeavours of scientists past can provide both inspiration and pleasure.}

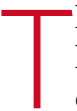

he face of science is always turned to the future - and that has been the downfall of many a historic scientific collection outside of the mainstream museums.

Take the eighteenth- and nineteenth-century natural-history collection begun in the 1770s by Lazzaro Spallanzani at the University of Pavia in northern Italy. In the 1930s, the half-million stuffed specimens - from giant turtles to gibbons - were cleared out to make room for a new faculty of law. The collection had become a slight embarrassment, a woefully old-fashioned way of doing science. After sojourning at a nearby palazzo, it was carelessly crammed into the attics of the local Visconti castle for storage. But even the finest address can host insects and microbes, and over the years the collection began to rot.

Similar fates befell other collections around Europe. At best, individual items would be given as amusing gifts to visiting scientists, at worst, the whole lot would be thrown away. Research interests had moved on, teaching methods modernized and, when the student numbers mushroomed after the 1960s, space was needed by new faculty members.

But in recent years a fresh awareness has developed about such relics, stirring first in Italy, whose scientific history, from the Renaissance to the start of the twentieth century, is arguably the most important on the continent. In 1991, the Italian association of university rectors set up a committee specifically to ensure that collections in universities were catalogued and cared for. In 2004, the Italian government was persuaded to amend its law on cultural heritage to include the protection of scientific objects, and the next year the Council
"In recent years a fresh awareness has developed about historic scientific collections." of Europe passed a like-minded resolution addressing universities across the continent.

Germany was alerted to what is hidden in the forgotten corners of its old universities when those in eastern Germany were required to make inventories at the time of reunification. A project to comprehensively digitize the collections in all the nation's universities is now under way.

Even so, there is little money across the continent for restoration. Back in Pavia, the university cannot find the resources to speed up the painstaking rescue of some of Spallanzani's specimens, and many will be lost forever. On the other hand, several of its other collections have survived well - and they form the basis of the first in Nature's new monthly series paying homage to relatively unknown collections and other scientific monuments off the well-beaten museum track (see page 526). The series will, we hope, inspire a greater interest in where scientists have come from, as well as encouraging those on the conference circuit with a few hours to spare to visit them. Delight is guaranteed.

\title{
A quantum of solace
}

\section{As the US writers' strike rolls on, now is the time for scientists to extend the hand of friendship.}

n the universe inhabited by James Bond, science manifests itself in two ways: as nifty gadgets for the good guys and as new ways to destroy or conquer the world for the bad guys. Can we expect this to change in the next instalment, the intriguingly titled Quantum of Solace? Probably not. The title is taken from an Ian Fleming short story about what is required for love, as recounted at a dinner party, not what is needed for a Bose-Einstein condensate as measured in a physics lab.

No, the real subjects of the 007 series are always charisma and violence; and violence, it seems, is the preoccupation of a globally dark Zeitgeist. The fine films nominated for Oscars this year mostly trade in crime, bloodshed and war. Science has useful things to say about our relationship with violence (see page 512), but it is the science that enhances violence, rather than seeks to understand it, that interests filmmakers. Why is that masked man doing all these impossible things? Radioactivity! Aliens! Genetic-modification experiments gone horribly awry!

Naturally there are exceptions. This year's Sundance Film Festival was awash with earnest science documentaries, all children of $A n$
Inconvenient Truth. A forthcoming Meryl Streep picture, Dark Matter, attempts with mixed success to dramatize the life of hardworking Chinese graduate students in cosmology - although it does feature bloodshed too. Russell Crowe has twice been nominated for an Oscar for playing real-life scientists in serious films - mathematician John Nash in A Beautiful Mind and research chemist Jeffrey Wigand in The Insider. But he won his Academy Award for Gladiator.

Scientists often complain that they can never change the way that science is portrayed in films, which seems as if the screenplays are written on a planet with different laws of physics. But, to quote an earlier Bond film, never say
"It is the science that enhances violence, rather than seeks to understand it, that interests filmmakers." never. Indeed, today is a propitious time for such intervention. The Writers Guild of America has been on strike since 5 November. Its members want a better deal in relation to online and other relatively new distribution channels. And boredom among these picketing scribes may well be at an all-time high - a recent update on the strike from The New York Times was headlined 'For Strikers, the Agony of Spare Time.

What better moment to saunter down to your local picket line, gather up a couple of film and television writers, and introduce them to the fascinations of the scientific life? Buying them a round might not hurt either; some of them have taken a serious financial hit. 